\title{
Granular Fine Cast Measurement
}

National Cancer Institute

\section{Source}

National Cancer Institute. Granular Fine Cast Measurement. NCI Thesaurus. Code C74769.

The determination of the amount of fine granular casts present in a urine sample. 